\title{
TABLE OF MALES OF THE NORTH AMERICAN SPECIES OF THE GENUS ASYNDETUS WITH DESCRIPTIONS OF SIX NEW SPECIES.
}

\author{
By M. C. Van Duzee. \\ Buffalo, New York.
}

This little genus is distinguished from Diaphorus by the latter part of the fourth vein being evanescent, and the costa ending at the tip of the third vein. The males of most of the species have conspicuous bristles at the tip of the abdomen as in Diaphorus.

The species described below are mostly from the western states where it is likely many new forms will yet be found.

\section{Table of Males.}

1. All tibiæ partly or wholly yellow . . . . . . . . . . 2 2

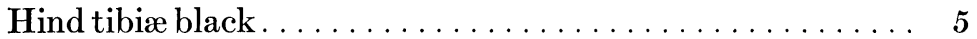

2. Fore tarsi modified, hind tibiæ blackened at base . . . . . 3

Fore tarsi normal, hind tibiæ blackened at tip . . . . . . . 4

3. First joint of fore tarsi incrassated. ....... ammophilus Loew. Second joint of fore tarsi with clavate, halter-like, yellow appendages...................... appendiculatus Loew.

4. Front and face very wide and covered with silvery pollen, palpi black (Fig. 4) . . . . . . . . . . . . . . . latus sp. nov.

Ground color of front and face showing through the white pollen; palpi rather large, white (Fig. 5) ........ caudatus sp. nov.

5. Fore and middle tibiæ black or brown ........... 6

Fore tibiæ yellowish, sometimes the middle ones also... . 8

6. Third antennal joint small, rounded, not longer than wide. 7 Third antennal joint large, twice as long as wide (Fig. 3)

nigripes sp. nov.

7. Mesonotum with a brown-dusted median vitta between two bluish-gray ones, length $2.5 \mathrm{~mm}$. . . . . . . fratellus Ald. Mesonotum not vittate............... interruptus Loew.

8. Third antennal joint somewhat quadrilateral in outline . . . 10

Third antennal joint rounded below and with a point at tip . . 9

9. Third antennal joint nearly straight above, fore tibiæ with short hair and very small scattering bristles (Fig.2) texanus sp. nov. 
Third antennal joint notched on the upper side, the arista inserted just above and before this notch; fore tibiæ with a row of rather long slender bristles the whole length (Fig. 6)

johnsoni sp. nov.

10. Fore tibiæ with long bristle-like hairs on the whole upper surface; third antennal joint twice as long as wide; second joint extending to near the middle of the third above, at which point the third is attached ............ 11

Fore tibiæ with only short hairs; third antennal joint but little longer than wide (Fig. 1) . . . . . . cornutus sp. nov.

11. Second antennal joint ending in sharp point at tip of which the third joint is attached; upper edge of third joint concave harbeckii VanDuzee

Second joint ending in a rounded projection near the middle of the third joint; third joint nearly straight above

syntormoides Wheeler

\section{Asyndetus cornutus sp. nov.}

Male: Length, 2-2.2 mm. Face wide, covered with white pollen which extends a little above the base of the antennæ; front wider than the face, green, shining; orbital cilia pale below with a few longer hairs near the oral margin; antennæ (Fig. 1) black, third joint somewhat lozenge-shaped with a rounded point at the upper corner, a little longer than wide, arista inserted on the upper edge near the base of the third joint. Thorax green, shining, with only slight traces of pollen; pleuræ more black. Abdomen green, becoming more coppery toward the tip, bristles at tip very small;
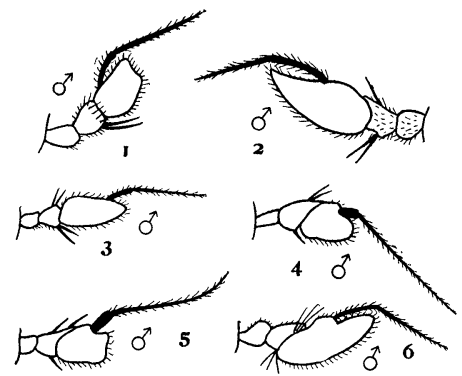

Fig. 1. Antennæ of Asyndetus. 1, A. cornutus, sp. nov.; 2, A. texanus sp. nov.; 3, A. nigripes sp. nov.; 4, $A$. latus sp. nov.; 5 , $A$. candatus sp, nov.; 6, A. johnsoni sp. nov. hypopygium concealed. Coxæ and femora black; fore and middle tibiæ yellowish, but sometimes rather dark, with short hairs and without or with scarcely perceptible bristles; hind tibiæ and tarsi and fore and middle tarsi from the tip of the first joint black. Tegulæ, their cilia and 
the knob of the halteres whitish. Wings grayish hyaline; fourth vein with the thin outer section bent back so as to reach the wing margin a little back of the apex of the wing.

Female: Agrees with the male very closely except that the third antennal joint is small and rounded and the general color is more golden or coppery.

Described from three males and five females taken at Saltair, Great Salt Lake, Utah, June 8; and two males and one female from Carriso Creek, San Diego Co., California. Type in the author's collection.

Easily distinguished from syntormoides Wheeler by the third antennal joint being shorter and the hair of the fore tibiæ being very short, while in Wheeler's species it is very long and conspicuous. From texanus sp. nov. it is separated by the third antennal joint being more angulated below near the tip, while in texanus it is evenly rounded below.

\section{Asyndetus texanus sp. nov.}

Male: Length, 2-2.8 mm. Face short, green with thin white pollen; front wider than the face, green, shining, without pollen except just above the antennæ; antennæ black, third joint more brownish, large, twice as long as wide, rounded below, nearly straight above (Fig. 2); arista inserted near the middle above. Thorax green, shining. Abdomen somewhat more coppery, incisures blackish; hypopygium small, imbedded, without visable appendages, the bristles at tip stout but short. Coxæ and femora black, shining, with slight green reflections; fore and middle tibiæ dark yellowish, with short hair; fore tibiæ with a few scattering bristles above; middle tibiæ with two bristles, one at first and one at second third; hind tibiæ black, shining; fore and middle tarsi about as long as their tibiæ, blackened towards their tips; hind tarsi black, shorter than their tibiæ. Tegulæ, their cilia and the halteres yellow. Wings grayish hyaline; third vein nearly straight; fourth vein delicate, gently bent, ending just back of the apex of the wing.

Female: Agrees with the male in color, venation, and bristles of the legs. Third antennal joint small, scarcely as long as wide, rounded at tip. 
Described from six males and five females taken at Galveston, Texas, May, by F. H. Snow; and Bill Williams Fork, Arizona, August. Type in the Kansas University collection.

One of the males from Arizona is steel-blue and the bristles of the fore tibiæ are scarcely visable.

This species is very much like snytormoides Wheeler, but is smaller, the third joint of the antennæ are more rounded below and smaller, and the fore feet are less hairy.

\section{Asyndetus nigripes sp. nov.}

Male: Length, $3.2 \mathrm{~mm}$. Face and front green; face with thin white pollen and narrower than the front; palpi brown; proboscis black; antennæ (Fig. 3) black, third joint more brownish, rather large, about twice as long as wide, pointed, somewhat conical in outline; arista dorsal; lateral and inferior orbital cilia pale ending in a few longer hairs on each side of the oral opening. Thorax dark green, shining, with but little pollen; base of abdomen green, the last three segments more coppery, there are several bristles extending somewhat upward and backward in the described specimen (their position may not be natural). Coxæ and legs black; femora with green reflections; pulvilli scarcely enlarged, white; all tarsi about the length of their tibiæ. Tegulæ, their cilia and the halteres pale yellow. Wings grayish hyaline; veins black; costa stout as far as the tip of the third vein where it ends; third vein nearly parallel with the second vein, ending far before the tip of the wing; the delicate fourth vein with only a slight bend, ending just back of the apex of the wing; cross-vein close to the root of the wing.

Female: Agrees with the male in general characters, but the third antennal joint is small, scarcely as long as wide, rounded at tip.

Described from one male and one female taken at Springdale, Los Angeles Co., Cal., April 29, on a rose bush; and a female from San Diego, Cal., May 1.

Asyndetus latus sp. nov.

Male: Length, $3.5 \mathrm{~mm}$. Face and front thickly covered with silvery pollen so as to conceal the ground color, very wide and with parallel sides; palpi and proboscis black, the former with stiff 
black bristles; antennæ (Fig. 4) black, third joint small, taken with the second rounded in outline; arista dorsal, its first joint short, second long and slender, scarcely pubescent; lateral and inferior orbital cilia white. Thorax and abdomen blue green; pleuræ and thorax with white pollen, which is thickest on the former; abdomen with the pollen thinner, when viewed obliquely with a central line and the incisures black; hypopygium small, bronze-green with several stout bristles at tip, its appendages scarcely visable. Coxæ and femora blue-green with white pollen; trochanters and tips of femora yellow; all tibiæ pale yellow; hind tibiæ with their tips black for a distance about equal to the length of their metatarsi, fore tarsi blackened from the second joint and middle tarsi from the tip of the first joint; fore and middle tarsi about one and a fourth times as long as their tibiæ; hind tarsi three fourths as long as their tibiæ and wholly black; fore and middle tibiæ with very short hairs and no bristles except one near the basal third of middle pair; hind tibiæ with slender bristles above; fore pulvilli not enlarged. Tegulæ, their cilia and the halteres pale yellow. Wings grayish hyaline; veins dark brown, yellowish at the root of the wings; costa rather stout from the tip of the first vein to the third where it ends; third vein runs nearly straight and parallel to the second until opposite the tip of that vein where it bends a little backward reaching the costa about half way from that point to the tip of the wing; the slender fourth vein bent forward then backward near its third fourth, ending back of the apex of the wing.

Described from one male taken at Bill Williams Fork, Ariz., in August, by F. H. Snow. Type in the collection of the University of Kansas.

Since writing the above I have found among my material taken at Carriso Creek, San Diego Co., Cal., two females which no doubt belong to the same species as the male described above.

\section{Asyndetus caudatus sp nov.}

Male: Length, $2.2 \mathrm{~mm}$. Face and front green, covered with white pollen which nearly conceals the ground color of the former; face a little narrower than the front but rather wide; palpi rather large, white; proboscis yellowish; antennæ (Fig. 5) black, third joint small rounded; arista dorsal; lateral and inferior orbital cilia white. Thorax and abdomen dark but bright green with but little pollen; hypopygium small, produced forward below into a 
short point and with several stout bristles at tip. Coxæ and femora black with green reflections; tips of coxæ, trochanters and base of femora yellow; tibiæ yellow, the tips of the hind pair brown; fore and middle tarsi about one and one fourth times as long as their tibiæ, infuscated from the tip of the first joint; hind tarsi black, shorter than their tibiæ; fore and middle tibiæ without bristles except a very slender one at basal third of middle pair; hind tibiæ with a few very small bristles. Tegulæ, their cilia and the halteres pale yellow. Wings hyaline, slightly tinged with gray; third vein nearly straight, parallel with the second, its tip far before the tip of the wing; the delicate fourth vein broken, its last portion somewhat forward of the basal part, but in a nearly parallel line with it, ending in the apex of the wing.

Described from one male from Bill Williams Fork, Ariz., taken in August, by F. H. Snow. Type in the Kansas University collection.

This can be separated from latus n. sp. by its smaller size narrower face and front, white palpi and straight third vein.

\section{Asyndetus johnsoni sp. nov.}

Male: Length, $2 \mathrm{~mm}$. Face and front green, the latter only slightly wider than the former; lower orbital cilia white and rather short; antennæ (Fig. 6) black, third joint large, rounded below but irregular in outline above. Thorax and scutellum dark shining green. Abdomen bronze green, towards the apex nearly black; hypopygium black; bristles at apex of abdomen distinct but rather slender. Coxæ black; femora brownish black with a row of slender hairs below; fore and middle tibiæ yellow; fore tibiæ with a row of hair-like bristles extending the whole length above, these bristles about as long as the thickness of the tibiæ; middle tibiæ with three bristles on the upper front edge; hind tibiæ brownish black with a number of small bristles above; fore and middle tarsi about as long as their tibiæ, infuscated from the tip of the first joint; hind tarsi brown, scarcely as long as their tibiæ, with rather conspicuous hair. Tegulæ, their cilia and the halteres yellow. Wings grayish hyaline; fourth vein bent backward but not distinctly broken at about the middle of the last section, ending back of the apex of the wing; cross-vein a little nearer the base of the wing than the tip of the first vein is. 
Female: Third antennal joint smaller than in the male with a nearly basal arista. Abdomen green, its insisures black with coppery reflections, in certain lights with a longitudinal black line in the center on the dorsum. Femora shining green; I cannot see the row of bristles on the fore tibiæ which appear in the male; fore and middle tibiæ yellowish, darker at base; hind tibiæ brownish black; fore and middle tarsi black from the tip of the second joint; hind tarsi black.

Described from one male and one female taken at Rowayton, Conn., August 4, by C. W. Johnson.

Type in the collection of the Boston Society of Natural History. This is very much like $A$. texanus sp. nov. but has the third antennal joint irregular in outline above, the fore tibiæ has a row of hairs or bristles above and the lower orbital cilia is distinctly shorter, especially near the proboscis.

CORA H. CLARKE.

Cora Huidekoper Clarke, the daughter of James Freeman and Anna Huidekoper Clarke, was born February 9, 1851, in Meadville, Pa., the home of her mother's family. From 1854 to 1897 she lived with her parents in Jamaica Plain, a suburb of Boston. After their deaths she moved to Mt. Vernon Street, Boston, where she remained until her own death April 2, 1916. Her summers were passed at a family seashore place in Manchester, Mass. Occasionally this was varied by a visit to Meadville or a trip abroad.

As a child, her health was delicate and for that reason she did not go to school until about thirteen years old, but during her school years, by diligence and conscientious study, she held her place with girls of her own age. When eighteen years old, she went to a horticultural school in Newton. She next studied at the Bussey Institution in Jamaica Plain and there enjoyed the advantage of having Francis Parkman as instructor. The class was small and sometimes she was the only pupil. Mr. Parkman perceived and appreciated her somewhat uncommon mental gifts and said to her father, "Your daughter has qualities of mind that most women do not possess."

She became a teacher in Miss Ticknor's Society for encouraging study at home and then and later her influence became a source of inspiration to many correspondents. Her own delight in these pursuits communicated itself to others. She founded a little club called The Science Club, which has maintained itself for many years, and was the leader of the Botany Group of the New England Women's Club. She was a member of several scientific societies, including the Cambridge Entomological Club and the Boston Society of Natural History, of which she was a member of the Council.

Miss Clarke was especially interested in botany and entomology and was known to entomologists by her interesting papers on the larval cases of the caddis-flies, and by her remarkable success in rearing gall-flies. The gall-midges (Cecidomyiidæ) were sent to Dr. E. P. Felt and he has described over thirty species new to science that were reared by Miss Clarke mostly in the vicinity of Boston and Magnolia, Mass. Three of the species were named in her honor, the others usually bearing the name of the plants upon which she found the galls. She reared many Hymenopterous gall-flies (Cynipidæ), five new species were discovered and named by H. F. Bassett, two of which were dedicated to her. A number of the little gall making moths were also reared, two of the latter being new species, named by Mr. Augustus Busck.

Miss Clarke was a skillful photographer and made excellent photographs of the galls. Some of these were mounted and arranged in two volumes which she presented to the library of the Boston Society of Natural History. Volume 1, Hymenopterous galls, contains 66 photographs and Volume 2, Dipterous galls, etc., 102 photographs.

The following are some of Miss Clarke's writings:

Description of Two Interesting Houses made by Native Caddis-fly Larvæ. Proc. Boston Soc. Nat. Hist., Vol. 22, pp. 67-71, 1882

Caddis Worms of Stony Brook, Psyche, Vol. 6, pp. 153-158, 1891. Galls Found Near Boston. Read before the Mass. Horticultural Society, Feb. 1, 1890. 11 pages.

New Missionary Work. Jour. N. Y. Botanical Garden, Vol. 3, pp. 62-69, 1902. Awarded the second prize of thirty dollars, competition of 1902, from the Caroline and Olivia Phelps Stokes Fund for the Preservation of Native Plants.

A suggestion for Summer Observation. Rhodora, Vol. 14, pp. 177-184, pl. 97-99, 1912. 

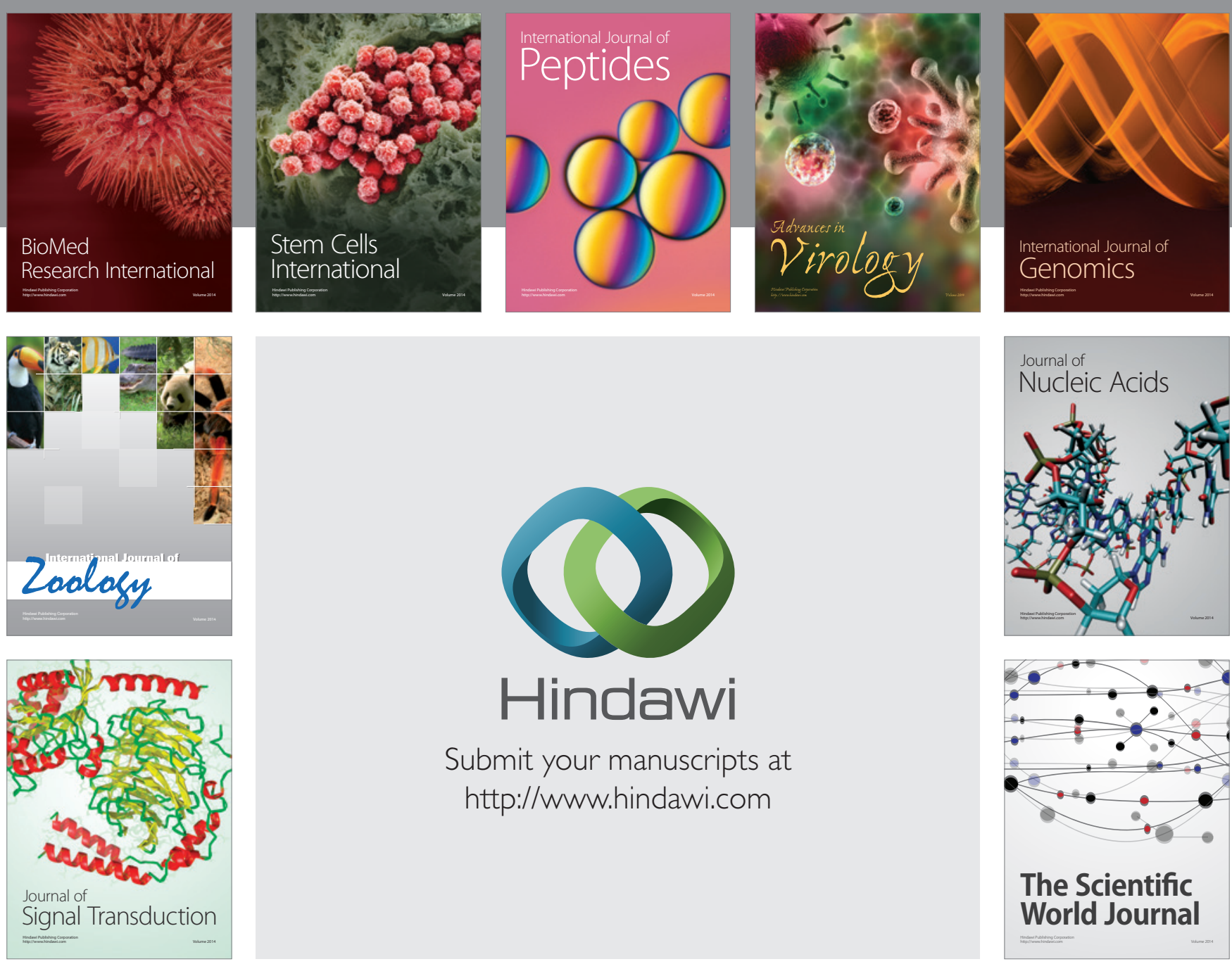

Submit your manuscripts at

http://www.hindawi.com
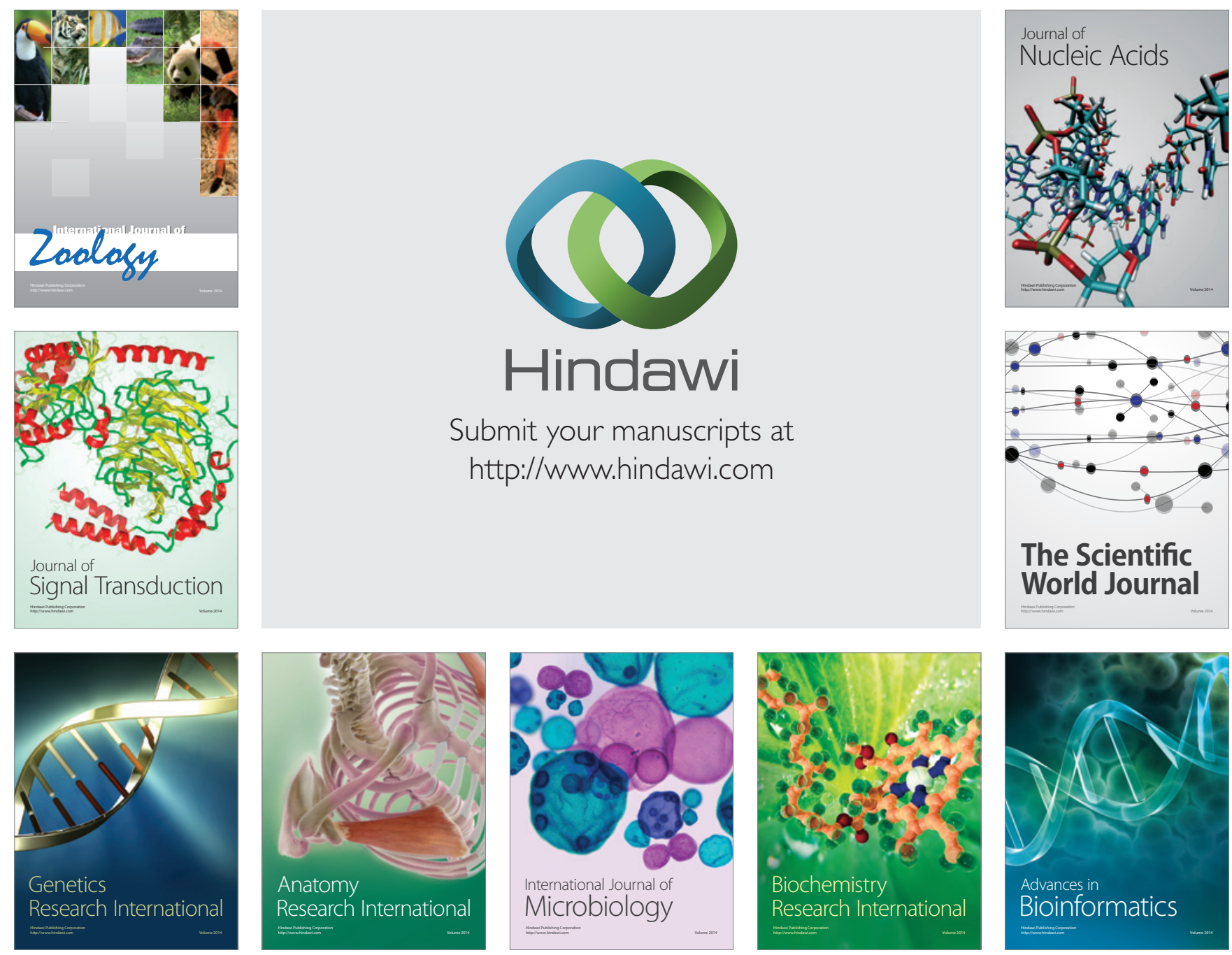

The Scientific World Journal
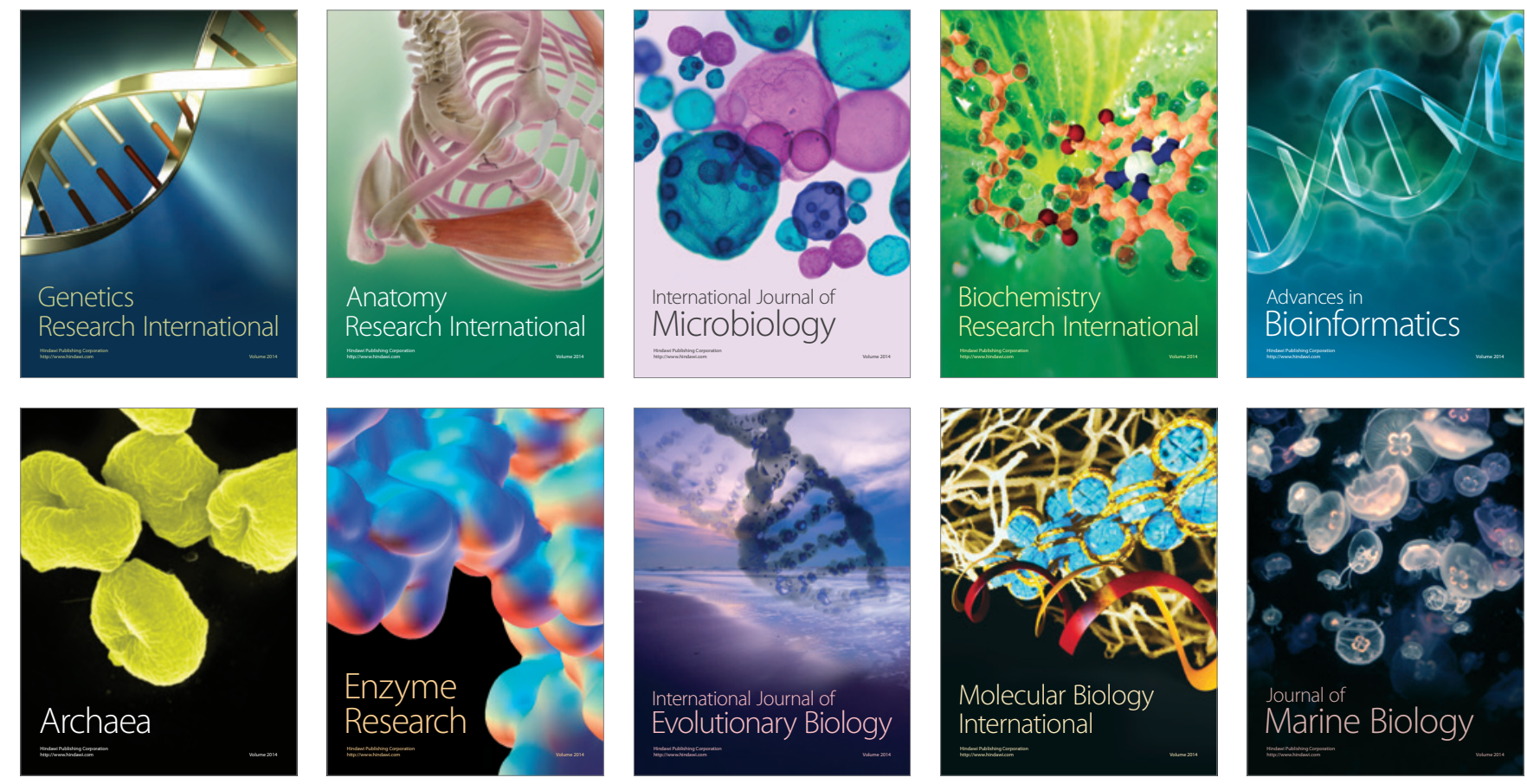